Please cite as: Cheliotis, L. K. and S. Xenakis (forthcoming, 2010) 'What's Neoliberalism Got to Do With It? Towards a Political Economy of Punishment in Greece', Criminology \& Criminal Justice: An International Journal (special issue on 'Neoliberalism and Penality: Reflections on the Work of Loïc Wacquant', edited by L. K. Cheliotis), 10(4).

\title{
What's Neoliberalism Got to Do With It? \\ Towards a Political Economy of Punishment in Greece
}

\author{
LEONIDAS K. CHELIOTIS AND SAPPHO XENAKIS ${ }^{1}$ \\ Queen Mary, University of London, UK, and Hellenic Foundation for Foreign and European \\ Policy, Greece
}

Over the last fifteen years or so, Loïc Wacquant has not merely helped lay the epistemological foundations for interrogating the relationship between neoliberalism and penality, nor has he confined himself to the empirical scrutiny of various and varying jurisdictions with a view to 'tracking the circulation of punitive discourses, norms, and policies elaborated in the United States as constituent ingredients of the neoliberal government of social inequality' (Wacquant, 2009a: 172). Wacquant has also grown to become one of the most vocal public critics of neoliberal penality internationally (see further Loader \& Sparks, this issue). Indeed, whilst travelling across the world in his capacity as a public intellectual, Wacquant came to acknowledge that 'the diffusion of neoliberal penality is not only more advanced, but also more diversified and more complex than portrayed [in his Prisons of Poverty].' For example, 'just as there are varieties of capitalism, there are many paths down the road to market rule, and thus many possible routes to the penalisation of poverty' (Wacquant, 2009a: 175). Hence, ultimately, the 'invitation' to his readers around the globe to take up and advance the study of penal policy and practice from a political economy perspective (ibid.: 176). The invitation arrives with no strings attached. To paraphrase Wacquant's own salute to Bourdieusian anti-dogmatism, an invitation to think with Wacquant is of necessity an invitation to think beyond Wacquant, and against him whenever required (Wacquant, 1992a: $x i v$ ).

Neoliberalism, according to Wacquant, is a 'transnational political project aiming to remake the nexus of market, state, and citizenship from above'. It is carried out by a 'new global ruling class in the making', spanning the heads and senior executives of transnational firms, high-ranking politicians, state managers and top officials of multinational organisations (e.g., the IMF and the World Bank), as well as cultural-technical experts in their employ (e.g., legal and media professionals) (Wacquant, 2009b: 306-307). Wacquant elaborates that neoliberalism entails not merely the reassertion of the dynamic of capitalist production and market exchange, but the articulation of four institutional logics: economic deregulation; the withdrawal of welfare protection; the cultural trope of individual responsibility; and an evermore expansive penal apparatus. Rather, then, than being a deviation from neoliberalism, penality is one of its essential components. More specifically, at the same time as publicly repudiating intervention in

\footnotetext{
${ }^{1}$ For helpful comments on earlier drafts, we would like to thank Ignacio González Sánchez, Nicola Lacey and Fergus McNeill.
} 
economic and social matters to ensure national competitiveness on the global stage, neoliberal states promote the "new "punitive common sense" forged in the United States' (Wacquant, 2009a: 162), which is to say that they elevate criminal insecurity and punishment to the frontline of governmental priorities. The underlying aim is to manage the social reverberations of 'advanced social insecurity' that neoliberal policies generate amongst the lower and middle classes. At the bottom of the class structure, punishment works to contain the disorders caused by the 'objective insecurity' of flexibilised wage labour and social-welfare retrenchment (ibid.: 93). Concurrently, punishing the poor creates a convenient outlet for the 'subjective' insecurity experienced by the middle classes, "whose prospects for smooth reproduction or upward mobility have dimmed as competition for valued social positions has intensified and the state has reduced its provision of public goods' (Wacquant, 2009b: 300). As such, punishment of the nether regions of social space compensates for the deficit in legitimacy suffered by state leaders on the economic and social fronts.

Our aim in this article is to put Wacquant's neoliberal penality thesis to the test within the Greek context. Of late, Greece has been the focus of considerable international attention, not simply in relation to the financial crisis there, but also in connection with issues of law and order. Wacquant, for his part, includes Greece amongst the countries that have joined the "Washington consensus" on punishment' (Wacquant, 2009a: 3). But whilst he addresses the Greek case in broad-brush cross-country comparisons, he does not delve into national historical complexities or other empirical details. This omission obscures important insights both into Greece as such and, more generally, into the relationship between neoliberalism and penality. Indeed, Greece readily lends itself to a critical evaluation of the degree to which penal policies incubated in America are globalised as part of the dispersion of neoliberalism. On the one hand, Greece has shared the general international trend in rising punitiveness over recent years. On the other hand, as a postdictatorial society, it has known intense periods of punitiveness within living memory. Furthermore, as a semi-peripheral country of the world economy, Greece has experienced a different trajectory of capitalist development compared to core Western states. ${ }^{2}$

We begin by examining trends in punitiveness in Greece as expressed through indicators of imprisonment (though, of course, one could follow Wacquant in exploring additional facets of the criminal justice system such as policing). Our method differs from Wacquant's in two important ways. First, rather than use one-day snapshot censuses of the prison population or annual totals of admissions to prison, we draw on indicators that allow a fuller grasp of the use of imprisonment: the annual caseload of offenders held in custody and the length of stay behind bars, as determined both by the length of sentence and the occurrence of early release. ${ }^{3}$ And second, rather than restrict the analysis to 'the past dozen years' (by which Wacquant (2009b:

\footnotetext{
${ }^{2}$ According to world-systems theory, 'core' and 'peripheral' states denote the winners and losers of international commodity exchange. 'A state is core (or peripheral) primarily because its production processes are highly profitable (or less profitable) and dominated by capital-intensive techniques, high technology, skilled and highly paid labour (or low profit, labour-intensive techniques and coerced low-wage labour). Accordingly, a state is semiperipheral, first because a "fairly even mix" of core-like and periphery-like activities fall within its borders'. Additionally, a semi-peripheral state is characterised by particularly sharp political struggles 'to affect state structures and policies in favour of [the] respective economic interests [of fractions of the bourgeoisie, workers, and external economic actors]' (Tayfur, 2003: 21-22).

${ }^{3}$ A more complete account still would also address immigration detention. Wacquant does employ data regarding the length of stay in prison and the variables underpinning it in his comparison of 'carceral evolution' in the US and France since the mid-1970s, but not when making reference to Greece and other jurisdictions such as Spain, Portugal and Italy, which prevents testing the argument in uniform depth. Our own analysis draws on data compiled by the National Statistical Service of Greece (NSSG) (see further Cheliotis, 2010a).
} 
88) means the period 1985-2000), we take a longer perspective. To locate the root causes of a given trend, it is necessary not only to trace its inception, but also to contextualise its evolution vis-à-vis past points of comparison. ${ }^{4}$ Although we discover ample compelling evidence of intense and growing punitiveness in contemporary Greece, it turns out that punitive trends anticipated the recent advent of neoliberal policy-making in the country, and indeed have starker precedents throughout the twentieth century. Whilst the former leaves neoliberalism with a limited penal role at most -that of enhancing, as opposed to engendering, the revitalised expansion of imprisonment-, the latter draws attention to the forms and functions of state power characteristic of the capitalist semi-periphery.

That neoliberalism bears little pertinence to the Greek case becomes all the more evident when we shift the focus of attention from the penal realm to the history of welfare and economic regulation in the country. True to its semi-peripheral status, Greece has long known both insufficient provision of social welfare -even if related expenditure has undergone an overall upward trend over the last fifty years- and widespread informal flexibility in labour relations. Although neoliberal reforms were introduced at the policy-making level as of the 1990s, they remained partial in scope, and were implemented slowly and patchily. In all, then, whilst we support Wacquant's call for 'bringing developments in welfare and criminal justice into a single theoretical framework equally attentive to the instrumental and expressive moments of public policy' (Wacquant, 2009a: 175), we find neoliberalism wanting as an explanation of punitiveness in Greece today. Instead, and to the extent that space allows, we point to the configuration of social, political, and economic tensions and conflicts representative of semi-peripheral societies. Sharing Wacquant's concern for 'epistemic reflexivity', whereby appreciating the procedures and effects of intellectual practice is a necessary condition of any critical theory of society (see further Wacquant, 1992b: 36-46), we conclude with some thoughts on the political dangers of the neoliberal penality thesis.

\section{Punitiveness in Greece: Tracing carceral trends}

In arguing the case that neoliberal penality has traversed US borders and spread throughout Europe and Latin America, Wacquant asks us to consider a host of trends, including booming rates of imprisonment, disproportionately lower levels of crime, and the over-representation of drug offenders, foreigners, and the poor (three commonly overlapping categories) in prison populations. Below we explore these facets of the neoliberal penality thesis within the Greek context. Our findings, on the one hand, confirm that the use of imprisonment in Greece has recently undergone strong inflation; that it bears little relevance to crime rates; and that it impinges principally on drug offenders, foreigners, and the poor. On the other hand, the rise of imprisonment began before the years associated with the onset of neoliberalism in the country, and has far more dramatic antecedents in living memory. Doubt is thus cast over the extent to which neoliberalism may have triggered a new era in Greek penal practice.

\section{'Carceral inflation': 1980-2006}

\footnotetext{
${ }^{4}$ In his account of 'hyperincarceration' in America, Wacquant himself returns to the early history of the prison in the sixteenth century in order to show that 'penal bondage developed, not to fight crime, but to dramatise the authority of rulers, and to repress idleness and enforce morality amongst vagrants, beggars, and assorted categories cast adrift by the advent of capitalism'. 'The rise of the prison', Wacquant concludes, 'was part and parcel of the building of the early modern state to discipline the nascent urban proletariat and to stage sovereignty for the benefit of the emerging citizenry. The same is true four centuries later in the dualising metropolis of neoliberal capitalism' (Wacquant, 2010: 7-8).
} 
Wacquant speaks of a 'swift and continuous increase in the incarceration rates in almost all the member nations of the European Union over the past dozen years' (Wacquant, 2009a: 88). Rightly, Greece does not qualify as an exception. Following a modest overall decline during the 1980s, imprisonment in the country has known an explosive growth over the last two decades or so.

Between 1980 and 1989, the annual total caseload of prisoners (including pre-trial detainees) fell by 6 percent, from 11,455 (or 119 per 100,000 inhabitants) to 10,763 (or 107 per 100,000 inhabitants). ${ }^{5}$ This was due to a drop in the caseload of convicted prisoners, significant enough to overshadow the contemporaneous rise in the caseload of pre-trial detainees. On the one hand, the caseload of pre-trial detainees increased by 22.8 percent between 1980 and 1989, from 3,269 (or 34 per 100,000 inhabitants) to 4,015 (or 40 per 100,000 inhabitants), with the proportion of pre-trial detainees amongst the total prisoner caseload also rising, from 28.5 percent to 37.3 percent. On the other hand, the caseload of convicted prisoners fell by 17.5 percent, from 8,186 (or 85 per 100,000 inhabitants) in 1980 to 6,748 (or 67 per 100,000 inhabitants) in 1989. Correspondingly, the share of convicted prisoners amongst the total prisoner caseload fell from 71.4 percent to 62.6 percent, although they still represented the bulk.

Trends were overturned between 1990 and 2006. The annual total caseload of prisoners (including pre-trial detainees) rose by 52.6 percent, from 11,835 (or 116 per 100,000 inhabitants) to 18,070 (or 162 per 100,000 inhabitants). This was not so much due to the rise in the caseload of pre-trial detainees, as in that of convicted prisoners. Whereas the caseload of pre-trial detainees increased by 15.3 percent between 1990 and 2006, from 4,247 (or 42 per 100,000 inhabitants) to 4,900 (or 44 per 100,000 inhabitants), the proportion of cases of pre-trial detainees amongst the total prisoner caseload fell, from 35.8 percent to 27.1 percent. By contrast, the caseload of convicted prisoners rose by a massive 73.5 percent, from 7,588 (or 75 per 100,000 inhabitants) in 1990 to 13,170 in 2006 (amounting to a rate of 118 per 100,000 inhabitants, an all-time high since the fall of the military junta in 1974). Correspondingly, the share of cases of convicted prisoners amongst the total prisoner caseload increased from 64.1 percent in 1990 to 72.8 percent in 2006.

\section{The 'crime-incarceration disconnect'}

Even though Wacquant (2009a: 88) argues that 'crime rose noticeably in European societies [between 1985 and 2000], whereas it stagnated in the United States', he speaks of the 'crimeincarceration disconnect' as a universal constant across spatial and temporal spans. '[C]omparative criminology', he writes, 'establishes beyond contest that there exists no robust correlation -in any country at any time- between the rate of imprisonment and the level of crime' (Wacquant, 2009b: 275; compare Nelken, this issue). As far as Greece is concerned, whilst (or, indeed, because) crime rates have not risen significantly, the 'crime-incarceration disconnect' thesis holds true. ${ }^{6}$

During the period 1980-2006, the annual total of police-recorded offences increased by 57 percent, from 295,353 to 463,750. Expressed as a rate per 100,000 inhabitants, the volume of crime rose by 35.8 percent, from 3,063 in 1980 to 4,160 in 2006. During the same period,

\footnotetext{
${ }^{5}$ Missing or ignoring the subtotal of pre-trial detainees cannot but understate the scale of imprisonment, especially since the average duration of pre-trial detention in Greece has in recent years been found to far exceed the minimum custodial sentence, and to be the highest in the EU (see further Cheliotis, 2010a).

${ }^{6}$ To anticipate crime-control ideologues: the modesty of the rise in crime is by no means the product of greater imprisonment (see further Cheliotis, 2010a).
} 
however, the subtotal of traffic offences (e.g., speeding and illegal parking) increased by 95.1 percent, from 114,138 to 222,720 , and by 68.8 percent as a rate per 100,000 inhabitants, from 1,184 to 1,998 . In good part, it follows, the rise in the total volume of offences was due to the rise in the volume of traffic offences, namely, offences of little criminological interest that only very rarely result in imprisonment. Indeed, once we deduct the volume of traffic offences from the total volume of offences, we observe that the annual number of police-recorded crimes rose by 33 percent (from 181,215 to 241,030), and by a modest 15 percent as a rate per 100,000 inhabitants (from 1,879 to 2,161$)^{7}$

One way or another, the rise in police-recorded offences cannot account for the fact that the annual total caseload of convicted and remand prisoners rose concurrently by 65.6 percent as an absolute number (from 10,703 in 1980 to 17,726 in 2006), by 43.2 percent as a rate per 100,000 inhabitants (from 111 to 159 ), and by 24.5 percent as a rate per 1,000 police-recorded offences (from 59 to 73.5 ) ${ }^{8}$ To put it differently, the likelihood of dealing with crime by way of imprisonment grew by a quarter during the period 1980-2006, whilst the likelihood of imprisonment under conviction grew even stronger: by 29.7 percent as such (i.e., from 41 to 53.2 as a ratio per 1,000 police-recorded offences), by 129.5 percent for convictions of a year or more (i.e., from 19.3 to 44.3 as a ratio per 1,000 police-recorded offences), and by 246.1 percent for convictions of three years or more (i.e., from 10.4 to 36 as a ratio per 1,000 police-recorded offences). At the same time, the likelihood of pre-trial detention rose by 29.4 percent as a rate per 100,000 inhabitants (from 34 to 44 ), and by 12.7 percent as a rate per 1,000 police-recorded offences (from 18 to 20.3).

\section{The 'preferred clients' of Greek prisons}

In examining what he describes as the spectacular rise of incarceration around Europe, '[f]rom Oslo to Bilbao and from Naples to Nottingham by way of Madrid, Marseille, and Munich', Wacquant notes the increasing share of drug addicts and dealers amongst prison populations. This, he suggests, is because, 'anti-drug policy serves as spear and screen for "a war against persons perceived as the least useful and potentially most dangerous parts of the population": the jobless, the homeless, the paperless immigrants, beggars, vagrants, and other social rejects of the city' (Wacquant, 2009a: 98; the quote is from Christie, 1994: 69). With reference to particular countries (e.g., England and France), Wacquant adds that the 'natural customers' of European prisons are also 'put away' for property offences such as burglary and for violations of immigration statutes (see further Wacquant, 2009a: 93-100). This analysis applies similarly to the Greek case.

During the period 1980-1989, the most common main conviction offence fell under the broad category of property offences (e.g., burglary, theft, and robbery), with the pertinent rate rising from 22.8 percent to 34.1 percent. Drug-related crimes (e.g., illicit drug use, drug trafficking) ranked second, their proportion in the total caseload increasing from 7.6 percent to 12.8 percent. Turning to the period 1990-2006, drug-related crimes became the most common main conviction offence, with the pertinent rate rising from 14.2 percent to 32.3 percent. The increase was most marked for drug trafficking (a crime often committed by drug addicts and commonly conflated by judges with possession of small quantities of drugs), which exploded from 56.8 percent to 94.2 percent as a proportion in the caseload of convicted drug offenders,

\footnotetext{
${ }^{7}$ Victimisation surveys clearly point to the same direction (see further Zarafonitou, 2010).

${ }^{8}$ The imprisonment figures reported in this section do not take account of prisoners held in connection with traffic offences.
} 
and from 8.1 percent to 30.5 percent as a proportion in the total caseload of convicted prisoners. Second ranked property offences, whose proportion in the total caseload fell slightly, from 28 percent to 25 percent. Special mention needs to be made of illegal entry into, departure from, or stay in the country, which grew to become one of the most common offence categories amongst convicted prisoners (and non-Greeks in particular). From 1993, when relevant official data were gathered for the first time, to 2006, it rose as a proportion in the total caseload from 6.9 percent to 13.9 percent.

Regarding the nationality of convicted prisoners, official data collection only began in 1996. Between then and 2006, the annual total caseload of non-Greek convicts rose by 140.5 percent, from 2,253 (or 404 per 100,000 non-Greek inhabitants) to 5,420 (or 559 per 100,000 non-Greek inhabitants). Correspondingly, the proportion of non-Greeks amongst the total caseload of convicts increased from 25.3 percent to 41.1 percent-four times higher than the estimated share of non-Greeks in the general population of the country. The level and nature of criminal involvement by non-Greeks, however, leave much unanswered as to the driving forces behind their overrepresentation in the total caseload of convicted prisoners. Between 2000 and 2006, for example, the police-recorded rate of non-Greeks amongst offenders was 1.6 times higher than the rate of Greeks, but the likelihood of imprisonment under conviction was 7.9 times higher for non-Greeks than the equivalent likelihood for Greeks. Over the same period, non-Greeks represented an average of 43.2 percent in the total caseload of prisoners convicted of a drug-related offence, but secondary analysis of police data reveals that the average proportion of non-Greeks amongst the perpetrators of drug offences only stood at 10.9 percent. Expressed in terms of the ratio of rates per 100,000 population, the average likelihood of a non-Greek being imprisoned under conviction for a drug offence was 9.4 times higher than the equivalent likelihood for a Greek, but the police-recorded rate of non-Greeks amongst the perpetrators of drug offences was only 1.5 times higher than the rate of Greeks. ${ }^{9}$

Finally, the majority of convicted prisoners are of working-class extraction, as illustrated, inter alia, by their occupational and educational background. In 1980, for instance, 57.4 percent in the caseload of convicted prisoners had been previously employed as skilled or unskilled labourers, or as service workers. The rate did not change by 1989, but rose from 59.2 percent in 1990 to 67 percent in $2006 .{ }^{10}$ In 1993, when official data were first collected on the educational level of prisoners, 61 percent in the caseload of convicted prisoners were either illiterate or had only completed primary education; a rate which increased to 75.4 percent by 2006 . Foreign convicts are vastly overrepresented in terms of working-class occupations, but not necessarily in terms of poor educational history (see, e.g., Aloskofis, 2005).

\section{'Carceral inflation' revisited}

The analysis so far lends support to core tenets of the neoliberal penality thesis. It would be too hasty, however, to assume that Greece has succumbed to a "new "punitive common sense" (Wacquant, 2009a: 162). As Wacquant indicates himself, levels of imprisonment cannot be explained without reference to the duration of sentences inflicted and served. He argues, for example, that 'the ballooning of the population behind bars [in Europe] results from the lengthening of sentences rather than from a strong inflation in admissions' (ibid.: 88). Elsewhere, for instance in his account of the 'strong upsurge in carceral demography' in France, Wacquant

\footnotetext{
${ }^{9}$ All this must be set against the background of multifarious disadvantages that render non-Greeks more likely to get caught in the criminal justice net (see further Cheliotis, 2010a).

${ }^{10}$ Recent changes in the classification of employment categories may have slightly inflated the numbers for 2006.
} 
also brings attention to the exacerbating role played by 'the withering away of early releases' (ibid.: 90). These variables are not merely apposite to the Greek case (see Cheliotis, 2010a); on close examination they reveal that penal punitiveness in the country commenced its upward course not in the 1990s, but in the 1980s. What this implies, as clarified later in the article, is that the rise in penal punitiveness predated the introduction of neoliberal reforms in Greece, and that neoliberalism cannot, therefore, explain the trend. ${ }^{11}$

During the period 1980-1989, the average length of stay in prison under conviction saw a significant 47 percent rise, from 3.8 months to 5.6 months. In terms of custodial sentences, there was a large expansion in the caseload of prisoners sentenced to a term of five to twenty years (by 77.2 percent, from 874 to 1,549), accompanied by an increase in the caseloads of prisoners sentenced to a term of one to three years (by 15.7 percent, from 1,607 to 1,860), three to five years (by 4.3 percent, from 854 to 891 ), and life imprisonment (by 12.5 percent, from 167 to 188). In 1989, the caseload of prisoners sentenced to a term of one to three years was the highest (27.5 percent), followed closely by the caseload of prisoners sentenced to a term of five to twenty years (22.9 percent). Not, then, that the judiciary was more liberal in their use of custodial sentences during the 1980s, but their traditionally punitive mentality (on which see further Cheliotis, 2010b) manifested itself in the expanding use of long custodial sentences, more so than in the use of custodial sentences as such.

As regards the period 1990-2006, the average length of stay in prison under conviction underwent a meteoric 1,337 percent rise, from 5.1 months to 73.3 months (or 6.1 years). In terms of custodial sentences, there was a huge expansion in the caseload of prisoners sentenced to terms of three to five years (by 323.3 percent, from 616 to 2,608), five to twenty years (by 332.7 percent, from 1,246 to 5,392), and life imprisonment (by 155.1 percent, from 270 to 689). The caseload of prisoners sentenced to a term of five to twenty years was by far the highest (40.9 percent) in 2006. There has thus been a durable parallel trend towards longer stays in prison under conviction and the use of ever-longer custodial sentences; a trend which gathered momentum during the 1980s and exploded thereafter.

Turning to early discharge from prison, during the period 1980-1989, the annual caseload of convicted prisoners released for any reason dropped by 35.3 percent, from 5,701 to 3,688, which was also a significant fall in proportion to the annual caseload of convicted prisoners, from 69.6 percent to 54.6 percent. As concerns more particularly the caseload of convicted prisoners released on parole, it increased by 17.8 percent between 1980 and 1989, from 381 to 449 , but this was only a small rise in proportion to the caseload of convicted prisoners, from 4.6 percent to 6.6 percent. We might deduce that the judiciary (Local Misdemeanours Councils in the case of parole) exhibited far greater propensity to pass long custodial sentences than to grant release on parole, and that parole eligibility was delayed in good part due to the ever-increasing length of custodial sentences. It is not implausible that lengthier sentences served as the means by which judges managed to control the release process before even offenders were put behind bars.

\footnotetext{
${ }^{11}$ One could also draw attention to the rise in the use of pre-trial detention during the 1980s, as this gave way to the rapid expansion in the use of imprisonment under conviction from 1990 onwards, which marked a qualitative rather than merely quantitative development. In much the same vein, one could point to the consistent overrepresentation of working-class populations in the caseload of convicted prisoners, notwithstanding widening ethno-national disparities. In fact, the very consistency in the use of imprisonment stands in stark contrast to the unevenness of the application of subsequent neoliberal reforms.
} 
Over the period 1990-2006, the annual caseload of convicted prisoners released for any reason increased by 46.1 percent, from 4,021 to 5,876 , but fell in proportion to the annual caseload of convicted prisoners, from 52.9 percent to 44.6 percent. Due largely to legislative interventions designed to pre-empt impending turmoil amongst prisoners, the caseload of convicted prisoners released on parole saw a huge 392.3 percent increase between 1990 and 2006, from 600 to 2,954, which was also a significant rise in proportion to the annual total caseload of convicted prisoners, from 7.9 to 22.4 percent. But this upward trend has not been consistent over time; indeed, it has been slightly reversed in recent years. In any case, parole alone could not have arrested the rise in the caseload of convicted prisoners. Although parole has become the most common reason for discharge of convicts, increasing as a percentile proportion of the caseload of all discharges from 14.9 in 1990 to 50.3 in 2006, the rates of discharge for other reasons (e.g., conversion of sentence into monetary penalty, work-related 'good-time' credits) either fell or rose insignificantly during the same period (see further Cheliotis, 2010a). With its discretionary powers left essentially untouched over the years, the judiciary has managed to ensure that 'front-door' entries to the prison system are not offset by 'back-door' releases (see further Cheliotis, 2010b).

\section{The punitive twentieth century}

A longer historical perspective provides a valuable lens through which to compare and contextualise punitive trends in Greece as manifested in the use of imprisonment. Such perspective immediately reveals the persistence of penal punitiveness in the country as a key mechanism by which the state has sought to depress labour wages and thereby sustain profitmaking for bourgeois elites under conditions of competition in the world economy. The goals may be common to all states, but are more likely to be pursued through direct coercion in peripheral and semi-peripheral societies, such as Greece (see further Tayfur, 2003).

Thus, for example, under the pretext of fighting Communism, the 1920s saw the Greek state introduce draconian measures against the spread of organised labour in order to maintain low wages. Particularly targeted were the large unions of the tobacco workers, the majority of whom consisted of refugees from Asia Minor. Repression of the working classes was intensified between 1936 and 1940 under the dictatorship of General Metaxas. Following a wave of social unrest provoked by the mix of low wages and rising costs of essential foodstuffs, Metaxas rose to power promising to implement authoritarian solutions to the 'labour question' (Mazower, 1991). His action on this promise was dramatically illustrated by indiscriminate mass arrests and deportations (Voglis, 2002). Notwithstanding scant knowledge of numbers, there is consensus that thousands were exiled and imprisoned on islands around Greece in the interwar period, mostly without trial (see further Mazower, 1991, 1997; Seferiades, 2005).

Apart from political exiles, available official data on the prison population show that between 1929 and 1937 the average annual caseload of convicted prisoners was 33,200, or 499 per 100,000 inhabitants. Indeed, the year 1932 saw the officially recorded all-time high of 37,809 cases of convicted prisoners; a rate of 578 per 100,000 inhabitants (close to five times the corresponding rate of 2006). Although the vast majority of imprisonment sentences were short (not beyond a year, and usually up to three months), and over a quarter of them were eventually converted into monetary penalties, the caseload of prisoners sentenced to longer terms was strikingly high by contemporary standards. In 1937, for instance, the caseload of prisoners sentenced to a term of a year or more was 116 per 100,000 inhabitants: 17.2 percent higher than the corresponding rate in 2006 (96), and nearly identical to the 2006 rate for the total caseload of 
convicted prisoners (118). There is evidence to suggest that at least part of the prison population at the time consisted of political detainees, whether serving a prescribed portion of their sentence in the 'main' prison system, or awaiting deportation to an island of internal exile, or under conviction by civil courts for violations of 'common' criminal laws (see, e.g., Kenna, 2001; Voglis, 2002; Seferiades, 2005).

Anti-communist measures dating from the 1920s were maintained with vigour in the immediate aftermath of World War II and throughout the Greek Civil War of 1946-1949. Following partial relaxation from the 1950s until 1966, they were again implemented in full force by the military junta of 1967-1974. Overwhelmingly, such measures reflected the politicoeconomic Cold War priorities of the US (which at the time dominated Greek political life), and met with the consent of those indigenous bourgeois elites that benefited from the distribution of American financial assistance to the country (Tayfur, 2003). In particular, leftist guerrillas who had fought for the liberation of occupied Greece in 1944 were swiftly subjected to systematic persecution, in stark contrast to Nazi collaborators. The year $1945 \mathrm{saw}$ an approximate 10,000 leftists sent to prison during what is known as the 'White Terror' (Voglis, 2002: 57). Furthermore, according to Voglis, '[a]t any given moment from 1947 to 1949, between 40,000 and 50,000 individuals were interned in prisons and camps' (ibid.: 63).

Whilst the 1950s signalled an era of greater political stability, this was disrupted over the next decade, when a competing faction of the domestic bourgeoisie gained ascendancy. The backlash came in 1967 with a military coup that reasserted privileges to foreign capital and its clientele in Greece (Tayfur, 2003). Over the seven years of the dictatorship, some 10,000 individuals were banished and 1,700 were sentenced to prison terms on political grounds (Voglis, 2002: 224). Based on official data, the average annual caseload of convicted prisoners during the same period stood at 13,448, or 152 per 100,000 inhabitants. Not included in these is the large unrecorded number of people subjected to short and brutal detention aimed to extract information about resistance activities and deter the general population from political engagement (Diamandouros, 1995). In 1974, the junta fell and democracy was established; a transition supported by a shift away from exclusive reliance on a declining US hegemon and towards the benefits of European Community membership. The new conditions heralded a temporary overall decline in the use of imprisonment. Between 1975 and 1979, the annual caseload of convicted prisoners fell by 16.1 percent, from 9,650 (or 107 per 100,000 inhabitants) to 8,088 (or 85 per 100,000 inhabitants), whilst the caseload of prisoners sentenced to a year or more remained stable.

Our dip into the history of twentieth-century Greece is not intended to demonstrate relative moderation in the use of imprisonment today, but rather points to a frightful prospect ahead. Indeed, the caseload of prisoners sentenced to a year or more has been heading rapidly towards the officially recorded levels of interwar years and appears destined to overtake them soon, given that the corresponding rate of prison admissions per 100,000 inhabitants is already significantly higher (e.g., 39 in 2006 as compared to 28 in 1937). Moving beyond description and cautioning, the recurrent fact of penal punitiveness in the country underlines the prominent role of state coercion in managing capitalist evolution in a semi-peripheral society. This is not to deny the possibility that Greek penal practice has been influenced more recently by neoliberalism. As suggested earlier, however, such influence cannot but have been limited to aggravating ongoing trends.

\section{Institutional (il)logics: Welfare retrenchment and economic deregulation in Greece}


The tenuous bearing of neoliberal penality on Greek reality is further clarified and qualified once we turn from the penal sphere to examine two other 'institutional logics' of neoliberalism: welfare retrenchment and economic deregulation. In Greece, trends in social expenditure have long been on the rise, including during the period associated with the coming of neoliberalism. But this is not to imply a developed welfare state, given that provision has remained characteristically inadequate. Indeed, the same degree of persistence has marked the flexibility of labour relations in the country. Despite their quasi-neoliberal features, both the welfare system and the labour market in Greece have been conditioned by the enduring semi-peripherality of the national economy. Underscoring this point is the late and fragmented introduction of neoliberal reforms, as well as their delayed and inconsistent application, which have ensured that Greece retain its reputation as a beacon of statism in Europe.

\section{The expansion of welfare expenditure}

Over the past half-century, Greece has experienced a general upward trend in public expenditure as a whole, and in welfare expenditure more specifically. Whilst this is no indicator of the extensiveness or quality of welfare provision, it does show that the neoliberal imperative of welfare retrenchment has been insignificant to the Greek case. As a percentage of GDP, total public expenditure in Greece rose from the 1960s onwards, but largely remained below European and OECD averages (see Economou, 2004; Pascual \& Alvarez-García, 2006; Paternoster et al., 2008; OECD, 2009b). Despite regular and recently amplified criticisms, the size of Greece's public sector workforce and related expenditure upon wages and public pensions have stayed close to average EU and OECD levels. Government employment, for example, was calculated at 14 percent of the total workforce in 2005, just below the OECD average (OECD, 2009a) ${ }^{12}$ Government wage expenditure had been lower than the European average in 1996, but as the latter fell towards 2008, Greek wage expenditure climbed above it (OECD, 2009b).

Expenditure on social protection at the national level (e.g., housing, health, disability, and social exclusion provisions, as well as social insurance for pensions and unemployment benefits) also grew incrementally after the establishment of democracy in 1974, from just over 10 percent of GDP to over 20 percent by 1998 and nearly 24 percent by 2005 (Maloutas \& Papatheodorou, 2004), though this still stood beneath the OECD average (Adema \& Ladaique, 2009). Whilst pensions have attracted a larger proportion of national social expenditure than the EU average (in 2005, for example, 51.2 percent of total benefits were spent on old-age and survivors benefits, as opposed to 45.9 percent amongst the EU-27), expenditure on pensions as a percentage of GDP has hovered close to the EU average over the 1990s and 2000s (Athens News Agency, 29 May 2003; Petrášová, 2008).

\section{The entrenched weaknesses of welfare provision}

Despite rising social expenditure, Greece has consistently lagged behind its European counterparts in promoting social equality. Sustaining this failure has been the historically piecemeal and minimal provision of welfare, compounded by a perverse tax environment. Once again, the historical pattern of provision belies the pertinence of neoliberalism, even if here paradoxically resembling it.

Social transfers, aside from pensions, have had far less impact on the risk of poverty in Greece than similarly-targeted transfers in the rest of the EU. In 2008, for example, Eurostat data

\footnotetext{
${ }^{12}$ It is also important to note that, unlike civil servants, public sector workers do not have a right to tenure, but are rather recruited on long-term contracts (Spanou, 2008).
} 
ranked Greece bottom amongst the EU-27 in terms of the effectiveness of its social transfers in reducing the risk of poverty (Seferiades, 2006; Wolff, 2010; see also Lampousaki, 2010). This is hardly surprising given that welfare benefits have not been directed to the most vulnerable members of the population. Over the 1990 s, the poorest 30 percent received less than 30 percent of all benefit payments, whilst those with middle-class incomes benefited disproportionately from non-pension transfers at the expense of both lower- and higher-income groups (Förster \& Pearson, 2002). Inequality has been further exacerbated by a system of taxation that redistributes wealth regressively, and by the prevalence of tax evasion (most common amongst the decile of the population with the highest level of income; see Papatheodorou, 2006; Matsaganis \& Flevomotou, 2010).

Equally, and unlike the vast majority of EU-27 member-states, Greece has never provided a guaranteed income to individuals in need who cannot rely on work-based benefits (Lampousaki, 2010). As emphasised by the European Committee of Social Rights (2010), persons in need and unable to cover their basic living costs from any other source of income are merely entitled to a one-off financial 'allowance' of $€ 234.50$ and free medical assistance. ${ }^{13}$ Until the mid-2000s, the provision of welfare benefits was dependent on the tax and insurance contributions history of potential recipients, with the consequence that those who had never worked, who had worked little, or who were long-term unemployed, were likely to have no entitlement to any form of welfare provision (see Papadopoulos, 2006). Moves over recent years to expand benefits coverage to those most deprived have not amounted to an income guarantee and benefits remain low and limited in duration (see European Committee of Social Rights, 2010; Lampousaki, 2010; EURES, 2010; Kousta, 2010). Rather than the state, it is families that have long been relied upon to provide safety nets (see, e.g., Karakatsanis, 2000; Papadopoulos, 2006).

As might well be expected, welfare provision is more generous for Greek nationals than for others. Greece has ratified a number of key international and European treaties which guarantee fundamental social rights for all, but it has been reluctant to recognise the status and needs of such groups as the Roma, refugees, asylum seekers and immigrants more generally (see, e.g., IHF et al., 2000; Sitaropoulos, 2002; Pavlou et al., 2009). ${ }^{14}$ Although rates of asylum applications to Greece are now amongst the highest in Europe, the country has maintained one of the lowest rates of refugee recognition (see Papadimitriou \& Papageorgiou, 2005; Eurostat 2010). Moreover, no clear legal basis exists for undocumented individuals and illegal migrants to claim emergency social assistance (European Committee of Social Rights, 2010), and, until the 1990s, basic social provision for refugees and asylum seekers was provided exclusively by domestic and international NGOs (Black, 1994).

Apart from partial coverage, another failing of welfare provision has been the inadequacy of benefits. Minimum welfare benefits have been set at such low levels that they leave the income of recipients on or below the poverty threshold. In 2007, for example, the minimum unemployment benefit for individuals without dependents was as low as $€ 174.75$ per month, well beneath the poverty line (European Committee of Social Rights, 2010). Since the 1990s, however, the retrenchment of provision in some key areas has coincided with expansion in others, or has even been overturned. Whilst, for instance, government funding and subsidies to

\footnotetext{
${ }^{13}$ The Greek National Health Service was established as recently as 1983 (see further Petmesidou, 2006).

${ }^{14}$ Roma and immigrants, as well as homeless and institutionalised populations, are overrepresented amongst the poorest and most vulnerable, but are excluded from national indices of poverty which draw on Household Budget Surveys (Tsakloglou \& Mitrakos, 2006; NSSG, 2010a).
} 
institutions such as residential homes and nurseries shrank (Petmesidou, 1996, 2006; Pavlou et al., 2009), projects emerged in housing, health, education, and training for vulnerable and disadvantaged sections of the population (stimulated and supported by the EU; see, e.g., Karakioulafis, 2007). In the case of pensions, the value of the minimum benefit fell beneath the poverty threshold in the second half of the 1990s (Petmesidou, 1996), but subsequently rose above it (European Committee of Social Rights, 2010).

In Greece, the weaknesses of welfare provision are nothing new. Socio-economic pressures have long been defused by the selective administering of political beneficence. Clientelism has ensured the co-option of specific sectoral interests by way of privileged access to state employment and protectionism. Indeed, over the last century, political affiliations and beliefs have played a central role in determining access to a wide range of social benefits provided on a discretionary basis by the state, including public sector employment (see, e.g., Pagoulatos, 2003; Petmesidou, 2006). Demands for welfarist reforms were also stunted by the absence of Fordist industrial development and its associated patterns of collective solidarity (Petmesidou, 1996; Petmesidou \& Mossialos, 2006). This was not mere coincidence, but rather an outcome of state design: support for small-scale enterprise and ownership -which would effectively curtail demand for the unified provision of social welfare nets- has reflected the recorded desire of Greek political elites to impede the growth of a working class in order to maintain socio-political stability (Mazower, 1991; Petmesidou, 2006).

State backing for the gradual and selective establishment of social insurance funds for specific professional sectors of the workforce was to leave a durable legacy of uneven provision and a large proportion of the population entirely uncovered (Petmesidou, 2006; Tikos, 2008). Particularly vulnerable have remained the self-employed and, of course, those working in the informal economy, both very sizeable sectors in EU comparison and both lacking union representation. The self-employed comprised over 21 percent of the total workforce in 2007, which was more than twice the EU-27 average (see Pedersini \& Coletto, 2009), whilst the informal economy has been one of the largest in the EU (Schneider \& Buehn, 2009; Matsaganis $\&$ Flevomotou, 2010). In Greece, then, highly inadequate welfarism has gone hand-in-hand with an under-regulated and 'flexible' economy.

\section{The flexible and under-regulated economy}

Reflecting semi-peripheral conditions, the weakness of labour representation in Greece (on which see Seferiades, 1999; Matsaganis, 2006) helps to explicate not only the relatively low level of wages in comparison with the rest of the EU, but also the fact that workers are at a far higher risk of poverty than the vast majority of their European counterparts. Throughout the 1990s, labour costs in the country were the second lowest in the EU (Papadimitriou, 2006). Greece also had the second highest proportion of working poor amongst the EU-27 in 2006 (Wolff, 2010), a year when half of all employees received net monthly incomes of between $€ 501$ and $€ 1000$ (Tikos, 2009), just above the poverty line (Eurostat, 2010). More generally, median household incomes have stood well below European averages (Tikos, 2009). Indeed, and despite allegations to the contrary (including by the OECD (2010a) and IMF (2009)), the Greek labour market has long been characterised by low wages, low indirect labour costs, and high flexibility (e.g., seasonal and part-time work, inadequate provisions for compensation and notice of job redundancies; high wage elasticity; European Committee of Social Rights, 2010; Livanos, 2010). As ironically evidenced by expressions of frustration amongst proponents of neoliberalism in Greece, the flexibility of the country's labour market has been entrenched in historical practices 
of informality rather than in formally codified rules (see further Mihail, 1996; Seferiades, 1999, 2003; Papadimitriou, 2006).

Aside from the engrained flexibility of the Greek labour market, however, not even the emergence of mass unemployment in the 1990s can be convincingly tied to neoliberalism. Firstly, unemployment had already begun to climb in the 1980s: between 1980 and 2000, the steepest rise was in 1981, when the annual rate increased by half (from 2.6 percent to 3.9 percent). Secondly, unemployment did not follow a consistent pattern during the period in which neoliberal policies were gaining ascendancy. Whilst the rate of unemployment rose over the 1990s, reaching a high of 12 percent in 1999 and henceforth overtaking the European average (Eurostat, 2009), it fell as of 2000 and, by the second half of the decade, had returned to levels of the late 1980s and early 1990s (IMF World Economic Outlook Database).

There is broad consensus that policies such as the dismantling of employment safeguards, the lowering of labour costs, the reduction of protectionism, the expansion of credit liberalisation, the deregulation of the market, and the privatisation of public services, all of which challenged middle-class interests, were effectively introduced in Greece only after the 1980 s, and were applied slowly and far less thoroughly than amongst the majority of OECD member-states (see, e.g., Staikouras, 2004; Pagoulatos, 2006; Tsakalotos, 2008; Spanou, 2008; OECD, 2010a). The most compelling illustration of the country's 'low reform capacity' has been the diluted output of repeated attempts since the 1990s to restructure the pension system (e.g., by extending the retirement age, raising contributions levels, and lowering pension ceilings) (Featherstone \& Papadimitriou, 2008: 114). Significant efforts to reform the labour market (e.g., by increasing compulsory overtime whilst reducing its costs, and relaxing limits on mass redundancies) emerged in the mid-1990s, and gathered momentum in the mid-2000s, but their overall impact is also considered to have been 'modest' (ibid.: 149). Privatisation was one of the policies which advanced furthest -in fact, between 2000 and 2008, Greece had one of the most active privatisation programmes amongst OECD member-states-, yet by 2010 the public sector was still judged 'relatively large', the use of price restrictions and market controls 'pervasive', and the general extent of government involvement in economic activity 'excessive' (OECD, 2010a: 7, 17; hence the redoubling of neoliberalisation endeavours over recent months (see e.g., Financial Times, 5 August 2010)).

Entrenched and emergent problems of the Greek labour market are thus not plausibly explained by reference to a blossoming of neoliberalism, but rather to the semi-peripheral conditions of the economy itself. Labour market trends have reflected a national economy superficially strengthened by processes of EU integration, but held back by its essential structural weaknesses (see, e.g., Tayfur, 2003; Featherstone \& Papadimitriou, 2008). Investment from, and market access to, the EU paved the way to the enlargement of the national labour force, attracting more women (Kanellopoulos \& Mavromaras, 1999), immigrants, and Greeks who would otherwise emigrate (Mihail, 1996). On the other hand, stubbornly low levels of investment in research and development activities (amongst the lowest in the EU; Seferiades, 2006), coupled with deep-seated features of the business sector (i.e., its composition by small and medium-sized enterprises specialising in low-tech, industry or service activities; Liagouras et al., 2003), helped to keep Greece trapped in its semi-peripheral state. Whilst stringent immigration policies were functioning alongside penal repression to confine the majority of immigrants to low-paid, menial and technical labour (Lawrence, 2005), Greeks would increasingly find their aspirations heightened in the meantime by expanding education and media consumption- unmet by the domestic job market. 


\section{Concluding remarks}

Over the past thirty years, the onslaught of consumer culture has accelerated the rise in social aspirations at the very same time that their satisfaction has become altogether more precarious. The significant drop in absolute levels of poverty experienced between the early 1960s and early 1980s stagnated thereafter, leaving the proportion of the population at risk of poverty one of the highest in the EU and OECD (see further Balourdos, 2004; Tsakloglou \& Mitrakos, 2006; Lampousaki, 2010; NSSG, 2010a; OECD 2010a). Whilst Greece also saw an overall reduction in income inequality from the mid-1980s to the mid-2000s (see OECD, 2009c), this slowed between 2001 and 2004 (Medgyesi, 2008), and levels remain amongst the highest of the EU-27 (see NSSG, 2010b). The structure of welfarist policies has played an important role in this respect, ensuring -in conjunction with rising levels of taxation- that there has been no significant positive net transfer from the state to labour since the 1980s. ${ }^{15}$

Yet Greece also experienced significant growth in household consumption from the 1990s onwards (by 22 percent between 1993/4 and 1998/9, and by 12.1 percent between 1998/9 and 2004/5; NSSG, 2001a). This was facilitated by the deregulation of both consumer and housing credit, which in turn produced a steep rise in household indebtedness (particularly amongst higher-income groups; Mitrakos et al., 2005). Although the ratio of household debt to national income has been comparatively low by European standards, the average annual rise in loans for housing and consumer goods has far outstripped that of the Eurozone in recent years (see Athanassiou, 2007). In 2009, a pan-European public opinion survey placed Greeks amongst those most likely to report serious financial problems and difficulties in keeping up with the payment of bills and credit commitments (Eurobarometer, 2010). Thus, consumerist expectations have advanced at a considerably faster pace than poverty and inequality have declined. Moreover, consumerism has expanded upon the shaky foundation of indebtedness, set against the background of rising unemployment.

To the extent, then, that imprisonment in Greece today serves to contain the anxieties and ensuing disorders at the lower levels of the class structure, it also helps displace middle-class insecurities onto 'actionable' fractions of the population. Although likely exacerbated by the advent of neoliberalism, perhaps especially by credit liberalisation, the roots of lower- and middle-class anxieties lie in the social, political, and economic tensions typical of semiperipheral societies: the particularly strained dynamics of social rights and mobility, political representation and state provision, and labour relations and profit-making. Our departure from Wacquant's model, it follows, turns on more than mere semantics; the findings of this article cannot be reconciled with his approach simply through expanding the interpretation of neoliberalism to incorporate proximate informal manifestations.

More than that, indiscriminate use of the concept of neoliberalism can all too easily encourage a collective amnesia; a focus on the present at the cost of an historically informed perspective. Implicit here is the fundamental political problem of being unable to overturn or resist a given trend without knowledge of the mechanisms that gave rise to it in the first place or may have given rise to it on previous occasions in the past. It is equally important to recognise the way in which the concept of neoliberalism can give succour to those nationalist agendas -

\footnotetext{
${ }^{15}$ According to a study comparing the provision of state benefits to employees and the contribution of employees to the state budget (via production and taxation) between 1958 and 1995, rising tax ratios and levels of unemployment since the mid-1980s have meant that there was no net gain by labour, despite the rise in real wages over the same period (Maniatis, 2003; see also Tsakalotos, 2008).
} 
whether of the Right or the Left- which locate the cause of all domestic malaise with the 'foreign finger' (see further Mazower, 1991). In the case of Greece, discourses critical of neoliberalism can thereby function to deflect attention from the culpability of local elites and the actual structural weaknesses of the national economy, even though foreign pressures are by no means to be ignored. Such effects are not dissimilar to what Wacquant (1997) has named in his earlier work 'the logic of the trial': disowning our own evils by excoriating others.

At a broader level, the Greek case points to the danger of occidentalist presumptions underlying the use of neoliberalism as an explanation for rising levels of punitiveness internationally. Theoretical frameworks based on Western experiences of capitalist development are problematically applied to states of the semi-periphery, given their very different social and economic trajectories. Indeed, by presuming the effective 'Americanisation' of contemporary Greece, the neoliberal penality thesis is no less prone than the discourse of 'globalisation' to lending neoliberalism appearances of inevitability. Just as it is vital to guard against representations of neoliberalism as a necessary condition for nation-states to compete in the global economy, so too it is imperative to avoid elevating the spread of neoliberalism to the realm of natural universal laws. Fatalism enhances vulnerability to ideologies, and these may consist in false pretensions of necessity as much as in nationalist 'logics of the trial'.

None of the above is meant to dismiss the possibility of a common cause underpinning increasing levels of punitiveness amongst so many societies over recent years. But this cause cannot be neoliberalism.

\section{References}

Aloskofis, W. (2005) Social and Penal Situation of Prisoners in the Judicial Prison of Korydallos: Differences between Natives and Foreigners. Report submitted to the Ministry of Justice [in Greek].

Athanassiou, E. (2007) 'Prospects for Household Borrowing in Greece and Their Importance for Growth', South-Eastern Europe Journal of Economics 5(1): 89-101.

Athens News Agency 'Greece Spends Same Percentage of GDP for Pensions as other EU States', 29 May 2003.

Adema, W. and Ladaique, M. (2009) 'How Expensive is the Welfare State? Gross and Net Indicators in the OECD Social Expenditure Database (SOCX)', OECD Social, Employment and Migration Working Papers No. 92. Paris: OECD.

Balourdos, D. (2004) 'Poverty', in D. Charalambis, L. Maratou-Alipranti and A. Hadjiyanni (eds) Recent Social Trends in Greece: 1960-2000, pp. 660-668. Montreal: McGill-Queen's University Press.

Black, R. (1994) 'Livelihoods under Stress: A Case Study of Refugee Vulnerability in Greece', Journal of Refugee Studies 7(4): 360-377.

Cheliotis, L. K. (2010a) 'Prisons and Parole', in L. K. Cheliotis and S. Xenakis (eds) Crime and Punishment in Contemporary Greece: International Comparative Perspectives. Oxford: Peter Lang AG.

Cheliotis, L. K. (2010b) 'Greece', in N. Padfield, D. van Zyl Smit and F. Dünkel (eds) Release from Prison: European Policy and Practice, pp. 213-236. Cullompton: Willan.

Christie, N. (1994) Crime Control as Industry: Towards Gulags, Western Style, 2nd edn. London: Routledge.

Diamandouros, P. N. (1995) 'Greece', in N. J. Kritz (ed.) Transitional Justice: How Emerging 
Democracies Reckon with Former Regimes, Volume II: Country Studies, pp. 243-282. Washington, DC: United States Institute of Peace.

Economou, D. (2004) 'Macro-Economic Trends', in D. Charalambis, L. Maratou-Alipranti and A. Hadjiyanni (eds) Recent Social Trends in Greece: 1960-2000, pp. 35-43. Montreal: McGill-Queen's University Press.

EURES (2010) Living and Working Conditions: Greece. Available at: http://ec.europa.eu/eures/main.jsp?acro=living\&lang=en\&parentId=0\&countryId $=\mathrm{GR}$

Eurobarometer (2010) Poverty and Social Exclusion. Brussels: European Commission.

European Committee of Social Rights (2010) European Social Charter: Conclusions XIX-2 (2009) (Greece): Articles 3, 11, 12, 13, 14 and Article 4 of the Additional Protocol of the Charter. Strasbourg: Council of Europe.

Eurostat (2009) Europe in Figures: Eurostat Yearbook 2009. Luxemburg: Office for Offical Publications of the European Union.

Eurostat (2010) Combating Poverty and Social Exclusion: A Statistical Portrait of the European Union 2010. Luxembourg: Publications Office of the European Union.

Featherstone, K. and D. Papadimitriou (2008) The Limits of Europeanisation: Reform Capacity and Policy Conflict in Greece. Basingstoke: Palgrave Macmillan.

Featherstone, K. and P. Tinios (2006) 'Facing Up to the Gordian Knot: The Political Economy of Pension Reform', in M. Petmesidou and E. Mossialos (eds) Social Policy Developments in Greece, pp. 174-193. Aldershot: Ashgate.

Financial Times 'Greece Praised for Swift Structural Reforms', 5 August 2010.

Förster, M. and M. Pearson (2002) 'Income Distribution and Poverty in the OECD Area: Trends and Driving Forces', OECD Economic Studies No. 34. Available at: http://www.oecd.org/dataoecd/16/33/2968109.pdf

IHF (2000) Report to the OSCE Implementation Meeting on Human Dimension Issues: Greece (Excerpts on Roma). Available at: http://www.greekhelsinki.gr/pdf/ihf-ghm-mrgg-oscereport-on-greece-roma.PDF

IMF (2009) Greece: Selected Issues: IMF Country Report 9/245.

Available at: http://www.imf.org/external/pubs/ft/scr/2009/cr09245.pdf

Ioakimoglou, E. (2000) Annual Economic and Employment Outlook. Athens: INE (Labour Institute of the Greek General Confederation of Labour (INE/GSEE). Available at: http://www.eurofound.europa.eu/eiro/2000/09/feature/gr0009185f.htm

Kanellopoulos, C. N. and K. G. Mavromaras (1999) 'Male-Female Labour Market Participation and Wage Differentials in Greece', Discussion Paper No. 70. Athens: Centre of Planning and Economic Research (KEPE).

Karakatsanis, N. (2000) 'Relying on Stop-Gap Measures: Coping with Unemployment in Greece', in N. G. Bermeo (ed.) Unemployment in Southern Europe: Coping with the Consequences, pp. 240-262. London: Frank Cass.

Karakioulafis, C. (2007) Youth and Work: The Case of Greece. INE/GSEE submission to the European Industrial Relations Observatory (EIRO).

Available at: http://www.eurofound.europa.eu/eiro/2005/12/tfeature/gr0512102t.htm

Kenna, M. E. (2005) The Social Organisation of Exile: Greek Political Detainees in the 1930s. Amsterdam: Harwood Academic Publishers.

Kousta, E. (2010) Government Grants Social Solidarity Aid to Vulnerable Groups. INE/GSEE submission to the European Industrial Relations Observatory (EIRO).

Available at: http://www.eurofound.europa.eu/eiro/2010/01/articles/gr1001019i.htm 
Lampousaki, S. (2010) Working Poor in Europe: Greece. INE/GSEE submission to a comparative study by the European Working Conditions Observatory (EWCO).

Available at: http://www.eurofound.europa.eu/ewco/studies/tn0910026s/index.htm

Lawrence, C. (2005) 'Re-Bordering the Nation: Neoliberalism and Racism in Rural Greece', Dialectical Anthropology 29(3-4): 315-334.

Liagouras, G., A. Protogerou and Y. Caloghirou (2003) 'Exploring Mismatches Between Higher Education and the Labour Market in Greece', European Journal of Education 38(4): 413426.

Livanos, I. (2010) 'The Wage-Local Unemployment Relationship in a Highly Regulated Labour Market: Greece', Regional Studies 44(4): 389-400.

Maloutas, T. and C. Papatheodorou (2004) 'Welfare System', in D. Charalambis, L. MaratouAlipranti and A. Hadjiyanni (eds) Recent Social Trends in Greece: 1960-2000, pp. 331343. Montreal: McGill-Queen's University Press.

Maniatis, T. (2003) 'The Net Social Wage in Greece 1958-1995', International Review of Applied Economics 17(4): 377-398.

Matsaganis, M. (2006) 'Muddling Through: The Trials and Tribulations of Social Security', in M. Petmesidou and E. Mossialos (eds) Social Policy Developments in Greece, pp. 147-173. Aldershot: Ashgate.

Matsaganis, M. and M. Flevomotou (2010) 'Distributional Implications of Tax Evasion in Greece', GreeSE Paper 31. London: Hellenic Observatory, London School of Economics.

Mazower, M. (1991) Greece and the Inter-War Economic Crisis. Oxford: Oxford University Press.

Mazower, M. (1997) 'Policing the Anti-Communist State in Greece, 1922-1974', in M. Mazower (ed.) The Policing of Politics in the Twentieth Century: Historical Perspectives, pp. 129150 Oxford: Berghahn Books.

Medgyesi, M. (2008) 'Income Distribution in European Countries: First Reflections on the Basis of EU-SILC, 2005', in I. G. Tóth (ed.) Tárki European Social Report, pp. 88-105. Budapest: Tárki.

Mihail, D. M. (1996) 'Unemployment and Labour Market Policies in Greece', Spoudai 46(1-2): 16-30.

Mitrakos, T. M., G. T. Simigiannis and P. T. Tzamourani (2005) 'Indebtedness of Greek Households: Evidence from a Survey', Bank of Greece: Economic Bulletin 25: 13-35.

NSSG (2010a) 'Statistics on Income and Living Conditions 2008: Risk of Poverty', Press release. Piraeus: NSSG.

NSSG (2010b) 'Statistics on Income and Living Conditions 2008: Income Inequality', Press Release. Piraeus: NSSG.

OECD (2009a) Country Note: Greece. Paris: OECD.

OECD (2009b) Economic Survey of Greece 2009: Enhancing Fiscal Viability. Paris: OECD.

OECD (2009c) OECD Factbook 2009: Economic, Environmental and Social Statistics. Paris: OECD.

OECD (2010a) Greece at a Glance: Policies for a Sustainable Recovery. Paris: OECD.

OECD (2010b) Jobs for Youth: Greece 2010. Paris: OECD.

Pagoulatos, G. (2003) Greece's New Political Economy: State, Finance and Growth from Postwar to EMU. Basingstoke: Palgrave Macmillan. 
Papadimitriou, D. (2006) 'The Limits of Engineering Collective Escape: The 2000 Reform of the Greek Labour Market', in K. Featherstone (ed.) Politics and Policy in Greece, pp. 159-179. London and New York: Routledge.

Papadimitriou, P. N. and I. F. Papageorgiou (2005) 'The New "Dubliners": Implementation of European Council Regulation 343/2003 (Dublin-II) by the Greek Authorities', Journal of Refugee Studies 18(3): 299-318.

Papadopoulos, T. (2006) 'Support for the Unemployed in a Familistic Welfare Regime', in M. Petmesidou and E. Mossialos (eds) Social Policy Developments in Greece, pp. 219-238. Aldershot: Ashgate.

Papatheodorou, C. (2006) 'The Structure of Household Income and the Distributional Impact of Income Taxes and Social Security Contributions', in M. Petmesidou and E. Mossialos (eds) Social Policy Developments in Greece, pp. 99-125. Aldershot: Ashgate.

Pascual, M. and S. Alvarez-García (2006) 'Government Spending and Economic Growth in the European Union Countries: An Empirical Approach', SSRN Working Paper. Available at: http://ssrn.com/abstract $=914104$

Paternoster, A., M. Wozowczyk and A. Lupi (2008) General Government Expenditures and Revenue in the EU, 2006. Brussels: European Communities.

Pavlou, M., K. Lykovardi, D. Hormovitis and I. Prokopi (2009) 'Housing Conditions of Roma and Travellers in Greece'. Hellenic League for Human Rights(HLHR)-KEMO.

Pedersini, R. and D. Coletto (2009) Self-Employed Workers: Industrial Relations and Working Conditions. Dublin: European Foundation for the Improvement of Living and Working Conditions (Eurofound).

Available at: http://www.eurofound.europa.eu/comparative/tn0801018s/tn0801018s_2.htm

Petmesidou, M. (1996) 'Social Protection in Greece: A Brief Glimpse of a Welfare State', Social Policy and Administration 30(4): 324-347.

Petmesidou, M. (2006) 'Tracking Social Protection: Origins, Path Peculiarity, Impasses and Prospects', in M. Petmesidou and E. Mossialos (eds) Social Policy Developments in Greece, pp. 25-54. Aldershot: Ashgate.

Petmesidou, M. and E. Mossialos (2006) 'Introduction: Addressing Social Protection and Policy in Greece', in M. Petmesidou and E. Mossialos (eds) Social Policy Developments in Greece, pp. 1-21. Aldershot: Ashgate.

Petrášová, A. (2008) Social Protection in the European Union: Statistics in Focus 48. Luxemburg: Eurostat, European Communities.

Available at: http://epp.eurostat.ec.europa.eu/cache/ITY_OFFPUB/KS-SF-08-046/EN/KSSF-08-046-EN.PDF

Schneider, F. and A. Buehn (2009) 'Shadow Economies and Corruption All Over the World: Revised Estimates for 120 Countries', Economics: The Open-Access, Open-Assessment EJournal.

Seferiades, S. (1999) 'Low Union Density amidst a Conflictive Contentious Repertoire: Flexible Labour Markets, Unemployment, and Trade Union Decline in Contemporary Greece', EUI Working Paper No. 99/6. Florence: European University Institute.

Seferiades, S. (2003) 'The European Employment Strategy Against a Greek Benchmark: A Critique', European Journal of Industrial Relations 9(2): 189-203.

Seferiades, S. (2005) 'The Coercive Impulse: Policing Labour in Interwar Greece', Journal of Contemporary History 40(1): 55-78. 
Seferiades, S. (2006) 'Employment Policy in the "European Employment Strategy" Era: What Prospects?', in M. Petmesidou and E. Mossialos (eds) Social Policy Developments in Greece, pp. 194-218. Aldershot: Ashgate.

Sitaropoulos, N. (2002) 'Refugee Welfare in Greece: Towards a Remodelling of the Responsibility-Shifting Paradigm?', Critical Social Policy 22(3): 436-455.

Spanou, C. (2008) 'State Reform in Greece: Responding to Old and New Challenges', International Journal of Public Sector Management 21(2): 150-173.

Staikouras, P. K. (2004) 'Structural Reform Policy: Privatisation and Beyond-The Case of Greece', European Journal of Law and Economics 17(3): 373-398.

Tayfur, M. F. (2003) Semiperipheral Development and Foreign Policy: The Cases of Greece and Spain. Aldershot: Ashgate.

Tikos, S. (2008) Social Partners and Opposition Parties Oppose Government Reforms of the Pension System. Submission by INE/GSEE to the European Industrial Relations Observatory (EIRO).

Available at: http://www.eurofound.europa.eu/eiro/2008/05/articles/gr0805029i.htm

Tsakalotos, E. (1991) 'Structural Change and Macroeconomic Policy: The Case of Greece (1981-85)', International Review of Applied Economics 5(3): 253-276.

Tsakalotos, E. (2008) 'Modernisation and Centre-Left Dilemmas in Greece: The Revenge of the Underdogs', GreeSE Paper No. 13. London: Hellenic Observatory, London School of Economics.

Tsakloglou, P. and T. Mitrakos (2006) 'Inequality and Poverty in the Last Quarter of the $20^{\text {th }}$ Century', in M. Petmesidou and E. Mossialos (eds) Social Policy Developments in Greece, pp. 126-143. Aldershot: Ashgate.

UN (2004) Greece: Public Administration: Country Profile. United Nations Public Administration Network. Available at:

http://unpan1.un.org/intradoc/groups/public/documents/un/unpan023214.pdf

Voglis, P. (2002) Becoming a Subject: Political Prisoners during the Greek Civil War. New York and Oxford: Berghahn Books.

Wacquant, L. J. D. (1992a) 'Preface', in P. Bourdieu and L. J. D. Wacquant, An Invitation to Reflexive Sociology, pp. ix-xiv. Cambridge: Polity.

Wacquant, L. J. D. (1992b) 'Toward a Social Praxeology: The Structure and Logic of Bourdieu's Sociology', in P. Bourdieu and L. J. D. Wacquant, An Invitation to Reflexive Sociology, pp. 1-59. Cambridge: Polity.

Wacquant, L. (1997) 'For an Analytic of Racial Domination', Political Power and Social Theory, 11: 221-234.

Wacquant, L. (2009a) Prisons of Poverty, expanded edn. Minneapolis and London: University of Minnesota Press.

Wacquant, L. (2009b) Punishing the Poor: The Neoliberal Government of Social Insecurity. Durham and London: Duke University Press.

Wacquant, L. (2010) 'Class, Race \& Hyperincarceration in Revanchist America', Daedalus 139(3): 1-17.

Wolff, P. (2010) Population and Social Conditions: Statistics in Focus 9. Luxembourg: Eurostat. Available at: http://epp.eurostat.ec.europa.eu/cache/ITY_OFFPUB/KS-SF-10-009/EN/KSSF-10-009-EN.PDF 
Zarafonitou, C. (2010) 'Fear of Crime', in L. K. Cheliotis and S. Xenakis (eds) Crime and Punishment in Contemporary Greece: International Comparative Perspectives. Oxford: Peter Lang AG.

Leonidas K. Cheliotis is Lecturer in Criminology and Deputy Director of the Centre for Criminal Justice at the School of Law, Queen Mary, University of London, UK. He is the editor of Roots, Rites and Sites of Resistance: The Banality of Good (Palgrave Macmillan, 2010) and The Arts of Imprisonment: Control, Resistance and Empowerment (Ashgate, 2010), and co-editor (with Sappho Xenakis) of Crime and Punishment in Contemporary Greece: International Comparative Perspectives (Peter Lang AG, 2010). He is currently working jointly with Sappho Xenakis on a book focusing on the political economy of punitiveness in modern Greece.

Sappho Xenakis is a Marie Curie Intra-European Fellow at the Hellenic Foundation for European and Foreign Policy in Athens, Greece. She is also an Associate of South East European Studies at Oxford (SEESOX), St. Antony's College, University of Oxford, UK. She is co-editor (with Leonidas K. Cheliotis) of a two-volume collection entitled Crime and Punishment in Contemporary Greece: International Comparative Perspectives (Peter Lang AG, 2010), and is currently working with Leonidas $\mathrm{K}$. Cheliotis on a book focusing on the political economy of punitiveness in modern Greece. 